\title{
Sønderborg-skipperes donationer til kirker på Gotland i første halvdel af 1700-årene
}

\author{
Af JÜRGEN BEYER
}

I 1704 og 1730 forærede skippere fra Sønderborg inventargenstande til to kirker på Gotland. Artiklen undersøger baggrunden for gaverne og identificerer skipperne ved hjælp af sønderborgske og gotlandske arkivalier. Det viser sig, at skipperne sejlede regelmæssigt mellem Gotland og de sydlige og vestlige østersøkyster, frem for alt med kalk. ${ }^{1}$

I to kirker på Nordøstgotland fortæller indskrifter, at kirkeinventar er blevet foræret af navngivne skippere fra Sønderborg. Rute Kirke huser et malet træpanel fra året 1730. I Hellvi Kirke findes et pulpitur med 13 malerier af apostle og Kristus, dateret 1704. Fra samme år har kirken et dåbsfad, ligeledes dekoreret med navnet på en sønderborgsk skipper.

Disse gaver er kun sporadisk blevet nævnt i den videnskabelige litteratur. Naturligvis registreres de i det pågældende bind af Sveriges kyrkor, og en bog om danske gotlandsfarere nævner dem i forbifarten. En kort omtale af malerierne på pulpituret findes også i en afhandling om malerkunst på Gotland og i en bog om Hellvi Sogn, men gavernes baggrund er ikke blevet undersøgt. ${ }^{2}$

Forbindelserne mellem Gotland og de danske kongers lande ophørte ikke med Brömsebrofreden i 1645 eller med den danske besættelse af øen fra 1676 til 1679. Fra de gotlandske landhavne, dvs. havnene uden for Visby, foregik der en livlig skibsfart, som skippere fra hertugdømmet Slesvig havde en stor andel i. Hvis vi tager året 1703, så opregner toldprotokollerne ikke færre end 342 afgange fra gotlandske havne. Omkring halvdelen af skibene stammede fra hertugdømmet Slesvig, f.eks. fra Egernførde, Femern, Flensborg, Haderslev, Marstal, Slesvig, Sønderborg eller Aabenraa. Blandt de mere betydningsfulde øvrige havne kan nævnes Danzig, København, Rostock og Wismar. ${ }^{3}$

For Sønderborg-skipperne spillede skibsfarten til Gotland en stor 


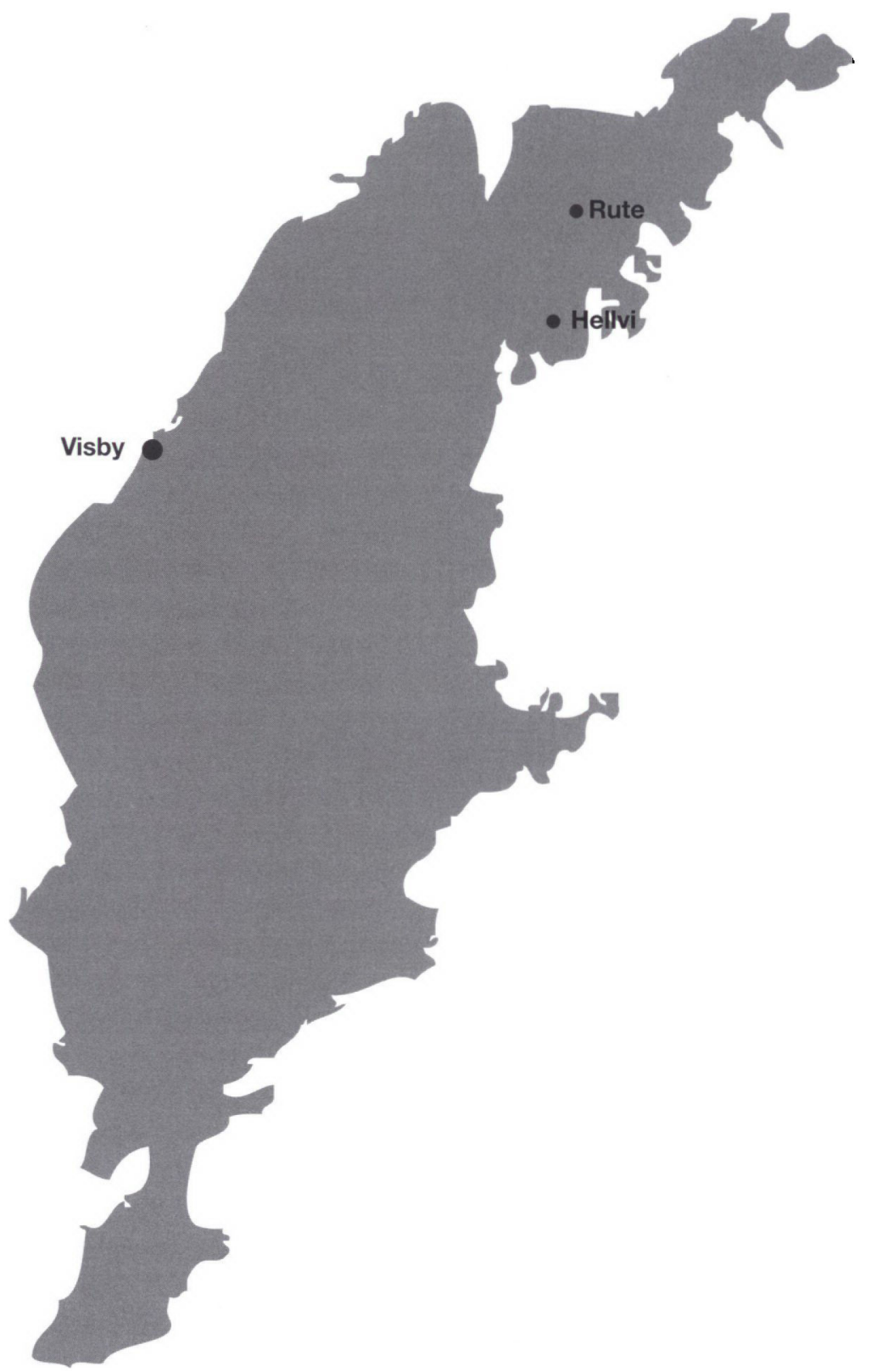

Kort over Gotland med byerne Visby, Hellvi og Rute. 
rolle frem til 1700, hvorefter den mindskedes. ${ }^{4}$ Det var dog just i denne sidste periode, at de efterlod sig minder i gotlandske kirker. Skipperne i Sønderborg var og er organiserede i et lav, der er det ældste skipperlav i det nuværende Danmark. Skipperlavet var ikke blot en standsorganisation. Det opfyldte samtidigt en række praktiske formål: bistand i økonomisk nød, forsyning med ballast, hjælp ved begravelser og forlig af stridigheder ang. søfarten. ${ }^{5}$

\section{Det sønderborgske kirkeinventar i Hellvi og Rute Kirker}

Det malede træpanel i Rute Kirke findes nu ved sydvæggen af tårnrummet. Den øvre del er udsmykket med guirlander, den nedre del med malede forhæng. I midten findes en inskription, der på svensk fortæller: »Till Gudz ära och Kyrckians prydnad hafwa föliande denna målning förährt. ANNO 1730 Christian Hööck. Mathias Rijper Jøns Jøranson Hophman och Hans Krabbe ifrån Sønderborg «.

Hellvi Kirke var dengang som nu anneks til Lärbro. Pulpituret står i kirkeskibets nordlige del. Over frisen med apostlene kan man læse: "Diesen Chor haben unterbenandte ${ }^{6}$ woterfahrne ${ }^{7}$ | schiffers $^{8}$ von Son I rburch, ${ }^{9}$ Zur Ge $1 \mathrm{~s}^{10}$ Ehre, Der kirch ${ }^{11} \mid$ Zirath, undt ih ${ }^{12} \mid$ Nahmens gedäc ${ }^{13}$ | auß Staffier ${ }^{14} \mid$ lassen; An ${ }^{15} 1704$ den 21 Selptembris, «. Under billederne står » $\varepsilon_{3}^{3}$ Christian Jürgensen,

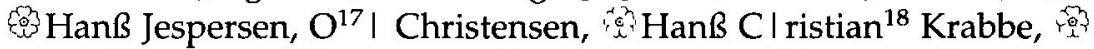
Andre ${ }^{19} \mid$ Krabbe, Christi ${ }^{21}$ | ahlman, Christian [M] I ichelsen, Can $^{2}$ Hanßen, $\mathrm{Niß}$ Ibsen, «. Selve billederne har også påskrifter, nemlig apostlenes navne i deres latinske form.

Ved en eller flere ombygninger (mere herom nedenfor) blev rammerne omkring billederne beskåret. Det førte til, at enkelte bogstaver forsvandt. Sådanne skærelinjer mellem panelerne er ovenfor angivet med »| «, men det er på trods af lakunerne ikke så vanskeligt at oversætte teksten: »Nedennævnte velerfarne skippere fra Sønderborg har den 21. september 1704 ladet udstaffere dette kor til Guds ære, kirkens udsmykning og deres navnes minde.« Navnene lyder i deres danske former: "Mikkel Ahlmann, Peder Andersen, Christian Jørgensen, Henning Nissen, Hans Jørgen Lassen, Hans Jespersen, O.[?] Christensen, Hans Christian Krabbe, Anders Krabbe, Lorenz?, Peder 


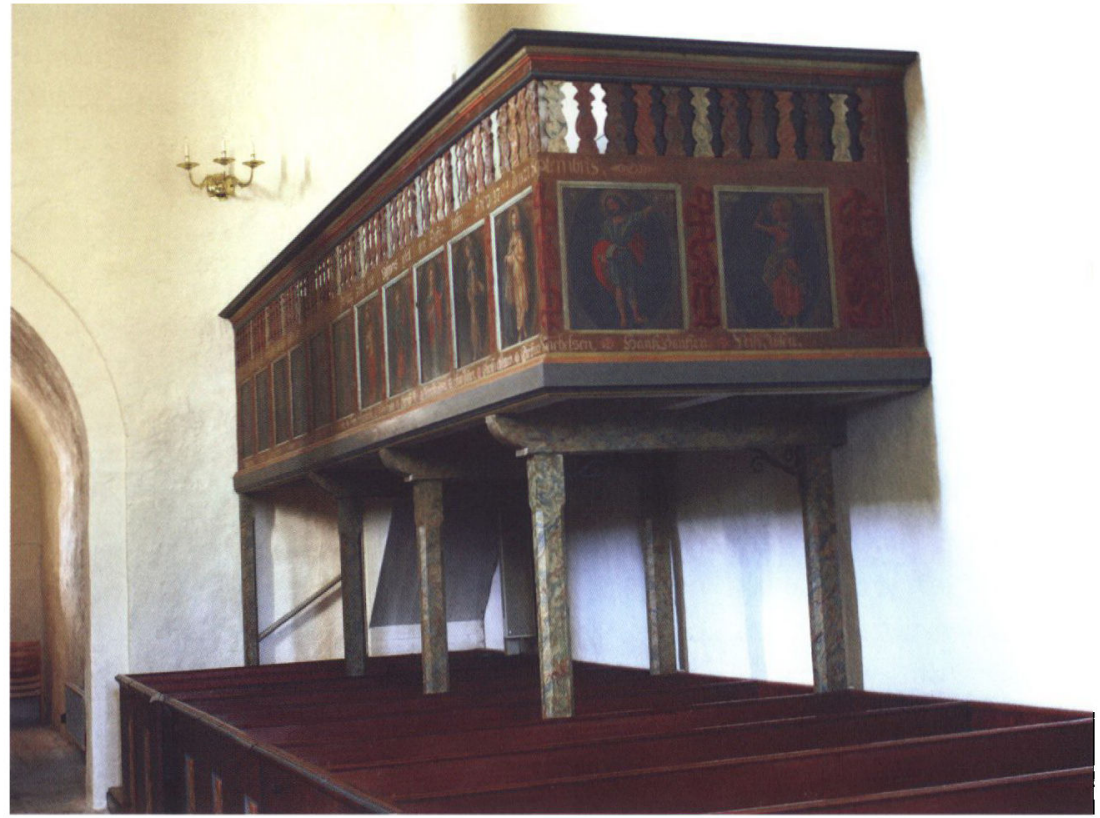

Pulpitur i Hellvi kirke. Foto: Jürgen Beyer.

Knudsen, Christian Fisker, Christian Ahlmann, Christian Mikkelsen, Hans Hansen, Nis Ibsen «. ${ }^{22}$

Desuden ejer kirken en anden gave fra en Sønderborg-skipper: Et dåbsfad af forsølvet kobberblik bærer indskriften: "SCHIFER - HANS . JASPERSEN · VON · SONDERBVRG ANNO 1704«. ${ }^{23}$

\section{Kilder}

Oplysninger om skipperne kan hentes tre forskellige steder: 1) Publikationer om og kilder fra skipperlavet i Sønderborg, navnlig skipperlavets protokol, der begynder med året 1681,2) Kirke- og byarkivalier fra Sønderborg og 3) Toldprotokollerne for Visby. ${ }^{24}$

Toldprotokollerne fortæller mest om skibenes navn, drægtighed og last, men de nævner også skippernes navne, hjemsted samt de havne, skibet sejlede fra eller til. Naturligvis oplyser toldprotokollerne også detaljeret, hvor meget told der blev betalt. Det er derfor, det omfattende bogholderi fandt sted - men i vor sammenhæng er disse beløb 
uinteressante. Toldprotokollerne indeholder værdifulde og hidtil uudnyttede oplysninger om, hvor Sønderborg-skipperne og deres kollegaer fra de øvrige slesvigske byer sejlede hen, og hvilke skibe de sejlede på. ${ }^{25}$ Åke G. Sjöberg beskriver - for en lidt tidligere periode - hvordan disse arkivalier blev til. Når et skib ville sejle fra en landhavn på Gotland, satte den lokale tolder et dokument op angående lasten. Dokumentet forsegledes, og skipperen rejste med det over land til Visby. På toldkontoret i Visby blev oplysningerne fra dokumentet indført $\mathrm{i}$ toldprotokollen. Efter at have betalt toldafgifterne, blev skipperen udstyret med et pas. Når han var kommet tilbage til havnen, kunne skibet lægge fra. For de indkommende skibe anvendtes en lignende omstændelig procedure. ${ }^{26}$

Enkelte ufuldstændige navne på pulpituret kunne kompletteres fra toldprotokollerne, men med en vis forsigtighed, dels fordi man uden de originale bilag fra landhavnene - ikke ved, hvorvidt der ved registreringen i Visby blev foretaget normaliseringer, dels fordi toldprotokollerne er ført på svensk. For de gængse person- og stednavne brugtes de tilsvarende svenske former (Christian Jürgensen kaldes f.eks. for "Christian Jöransson «, København for »Kiöpenham(b)n «). Mere sjældne navne derimod blev nok overført ad hoc til en svensk stavemåde. Her kan både skipperens udtale, skrivernes dialektale baggrund og deres kendskab til fremmede sprog have haft indflydelse på retskrivningen.

Mens skippere fra Rostock og Lübeck formentlig talte plattysk på Gotland, er det ikke givet på forhånd, om deres kollegaer fra Sønderborg eller Aabenraa benyttede sig af plattysk, højtysk, sønderjysk eller rigsdansk. Egernförde optræder gennemgående som "Ekelferde“, og Femern kaldes generelt for »Femmern«. Slesvig optræder som "Sleßwijk«. Sønderborg hedder slet og ret "Sønderborg(h)«. For Haderslev anvendes det tyske navn: »Hadersleben « (også »Hadersleb«). Flensborg optræder som »Flensborg«. »Åppenråde« gengiver måske en plattysk udtale for dansk Aabenraa og tysk Apenrade. Også ved nogle af de andre navne kan plattysk have spillet ind, bl. a. ved navnene på -borg. »Ertskiöping" er sandsynligvis Ærøskøbing.

Rute Sogns arkivalier gik desværre op i røg sammen med Rutes præstegård i $1871 .{ }^{27}$ For årene 1725 til 1732 er heller ikke de indog udgående toldprotokoller bevaret på Landsarkivet i Visby. Derfor beskæftiger artiklen sig primært med Hellvi Kirke. 


\section{Søfart på Gotland omkring 1700}

Den uden sammenligning vigtigste ladning, som skipperne fra Sønderborg tog om bord i Hellvi og Rute Sognes havne, var kalk, både læsket og ulæsket. I meget mindre målestok medførtes træ. ${ }^{28}$ I løbet af det 17. århundrede var kalkbrud og kalkbrænderier blevet vigtige erhvervsgrene på Gotland. Hellvi Sogn var et centrum i denne produktion, der var rettet mod eksport. ${ }^{29}$ Godset, som blev fragtet til Gotland, var derimod mere varieret. Ofte var det malt, men det kunne også være korn eller tagsten. Andre gange var det blot ballast. ${ }^{30}$

Mange skibe optræder jævnligt med omtrent en måneds mellemrum i toldprotokollerne. Det var åbenbart den tid, det tog at sejle til den sydlige eller vestlige del af Østersøen, fortolde varerne, losse skibet, tage ny last ind, fortolde varerne, sejle tilbage til Gotland, fortolde varerne, losse skibet, tage ny last ind og igen fortolde varerne.

Der blev ikke sejlet om vinteren. Tidspunkterne for årets første og sidste skib på Gotland var ifølge de udgående toldprotokoller i 1701 den 18. marts og 13. december, i 1702 den 22. februar og 2. december, i 1703 den 26 . marts og 13. oktober, i 1704 den 16 . marts og 8 . november samt den 9. marts og 18 . november i $1705 .{ }^{31}$

På Gotland koncentrerede de fleste skippere fra Sønderborg deres aktiviteter til havne i Hellvi Sogn, dvs. Hide, Lörje, Kyllaj, Vallevik og Värne. ${ }^{32}$ Sammenlagt stod disse havne for ca. $17 \%$ af den gotlandske eksport i $1694 .^{33}$ Sønderborg-skippere, der sejlede på andre gotlandske havne, optræder ikke på pulpituret. Derimod har ikke alle Sønderborg-skippere, der anløb Hellvi Sogns havne, ydet bidrag til pulpituret. ${ }^{34}$

Fra Gotland sejlede vore skippere videre til bl.a. Elbing, Königsberg eller København. Det kan konstateres, at der ofte optræder små grupper af skibe fra samme hjemby under samme dato. Åbenbart sejlede man gerne i mindre konvojer for at øge sikkerheden.

\section{Skipperne}

Nu til skipperne, der bliver nævnt på pulpituret. De behandles i alfabetisk rækkefølge. Navnene anvendes her - når der ikke er tale om direkte citat fra kilderne - $\mathrm{i}$ deres højtyske form. ${ }^{35}$ Skipperne lod højtysk bruge på pulpituret, anvendte det i skipperlavets protokol ${ }^{36} \mathrm{og}$ synes også at have givet deres skibe højtyske navne. Hvordan de talte 


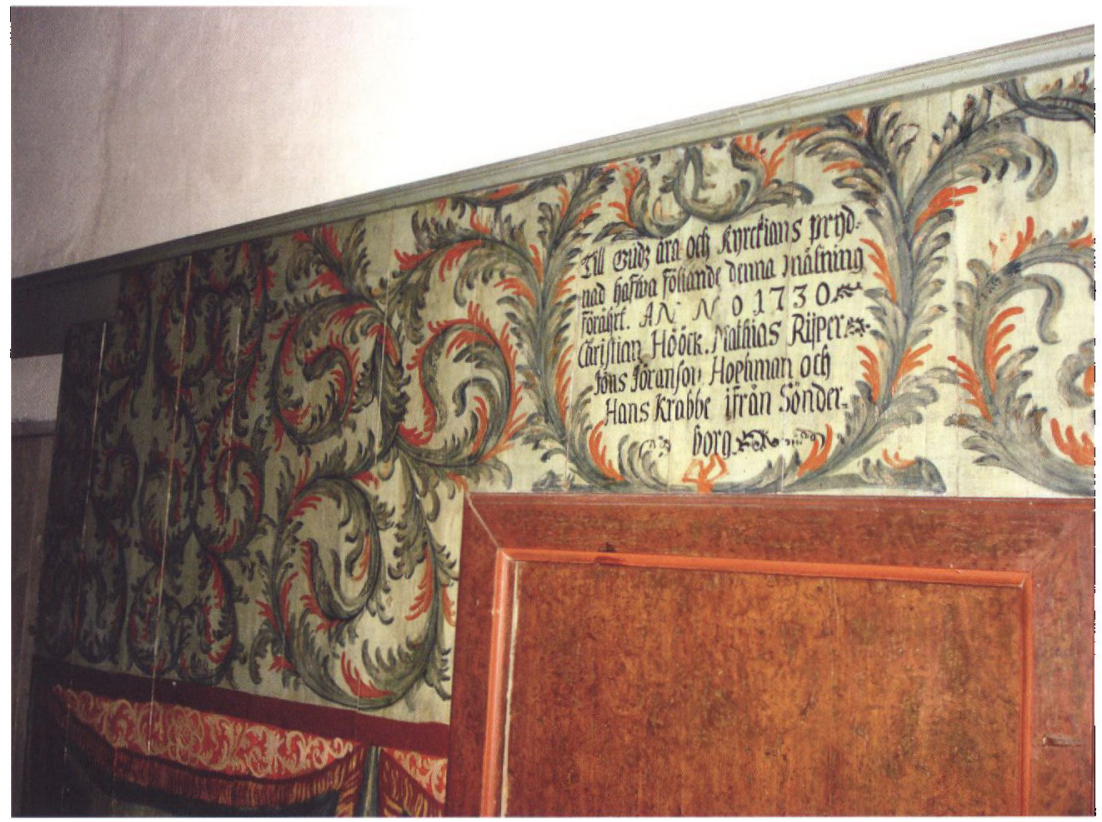

Panel i Rute kirke (detalje). Foto: Jürgen Beyer.

med hinanden eller med embedsmænd og havnearbejdere på Gotland, er et helt andet spørgsmål. Det vender jeg tilbage til senere. Skipperfamilierne i Sønderborg stammede i øvrigt fra hertugdømmet Slesvig eller fra Danmark. ${ }^{37}$ Deres familiebaggrund var altså både dansk og tysk.

Christian Ahlmann var medlem af skipperlavet i 1681 . I 1707 blev hans skib kapret af svenskerne, og han døde som fange i Göteborg i $1709 .{ }^{38}$

Michael Ahlmann blev født den 25. februar 1649. Han var søn af Sønderborg-borgmesteren Jacob Iversen AhImann. I 1680 blev han gift med Brigitte (Bertha) Jepsen. ${ }^{39}$ Han var i 1681 medlem af skipperlavet og blev i 1682 skaffer. I 1683 kautionerede han, da skipperlavet gav en kredit på 20 mark til Matthias Petersen. De følgende år - indtil Petersens død - var det Ahlmann, der betalte renterne. I 1684 var han med til at bekoste en ny lavskiste. ${ }^{40}$ Han blev valgt ind i lavets bestyrelse i $1686 .{ }^{41}$ I 1688 befandt han sig i fangenskab hos nordafrikanske sørøvere - en ikke så sjælden skæbne ved denne tid. ${ }^{42}$ Skipper- 
lavet bevilgede 50 mark til at frikøbe ham. ${ }^{43}$ Det lykkedes åbenbart. Den 17. februar 1690 deltog han i lavsfesten i Sønderborg. Under Ahlmanns fravær betalte hans kone renterne for Matthias Petersens lån. ${ }^{44}$ I 1706 blev han valgt til skjørmand, dvs. næstformand, for skipperlavet. ${ }^{45}$ Han døde sandsynligvis i $1711 .^{46}$ Den 2 . maj 1703 sejlede han med sin 25 læster store krejert »unge Tobias« eller »Tobias« fra Slite (som ligger lidt syd for Hellvi) til Flensborg og den 6. juni fra Vallevik til København. ${ }^{47}$

Peter Andersen blev optaget i skipperlavet i 1706. I 1700 skulle han betale en bøde på 12 skilling, fordi hans skorsten ikke var rengjort. ${ }^{48}$ Han sejlede med en 20 læster stor skude ved navn "Salvator «. ${ }^{49}$

En O. Christensen synes ikke at have været medlem af skipperlavet, men kan godt have været en skipper fra Sønderborg. Flere af byens skippere var ikke medlem af lavet. ${ }^{50}$

Christian Fischer er sandsynligvis den Christian Hansen Fischer, der blev optaget i skipperlavet i 1705. Også i toldprotokollerne kaldes han for "Christian Hansson Fisker", og hans skude "Swan" angives til en størrelse på 13 læster. Christian Fischer skal i løbet af seks år have mistet tre skibe ved kaperi eller forlis. Han tilbragte mere end ét år $\mathrm{i}$ svensk fangenskab. ${ }^{51}$

Hans Hansen blev medlem af skipperlavet i 1706. I 1711 optræder han i Sønderborgs bøderegister: "Hans Hansen har gjort Anna Jürgens her i byen gravid. Da det blev kendt, begav de sig - efter at have betalt kaution - ud på landet og blev forlovet dér.“ Der står ikke noget bødebeløb, men en bemærkning skrevet af en anden hånd: "giver til fromme formål«, og dermed skulle beløbet ikke registreres i bøderegistret, som egentlig er en indtægtsfortegnelse. ${ }^{52}$ Hans skib var en 14 læster stor galiot ved navn »Pelikan«.

Nis Ibsen blev medlem af skipperlavet i 1704. I 1708 var han skaffer. ${ }^{53}$

En Hans Jasparsen (Jespersen) var medlem af skipperlavet i 1681, men en anden Hans Jasparsen blev optaget i 1694. En Hans Jasparsen blev valgt til skaffer i 1696, blev medlem af bestyrelsen i 1703 og var "kirkeældste « $\mathrm{i} 1705 .{ }^{54}$ Jespersens skib var en 24 læster stor skude ved navn "V. [=Unge?] Tobias«. På pulpituret staves navnet Jespersen og på dåbsfadet Jaspersen. Det er muligt, at vi her har at gøre med to forskellige personer.

Christian Jürgensen blev optaget i skipperlavet i 1695, blev skaffer i 1698 og medlem af bestyrelsen i $1705 .^{55}$ I 1710 måtte han - som også 


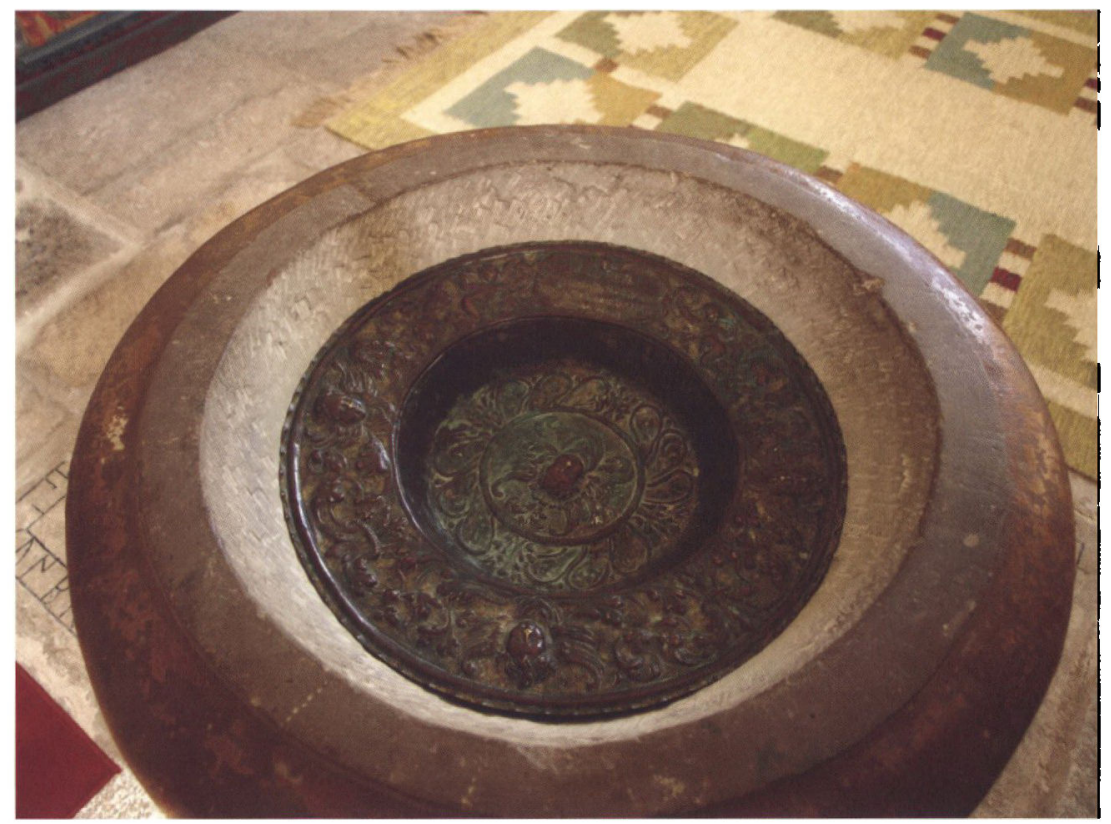

Dåbsfad i Hellvi kirke. Foto: Jürgen Beyer.

syv andre skippere - betale en bøde på 12 skilling, fordi han ikke havde betalt gebyret til skibbrofogeden (brïgken Vogt). ${ }^{56}$ Hans skib var en 28 læster stor krejert ved navn "Tobias«. Det var det største af de her nævnte skibe. Jürgensen sejlede fra Kyllaj til København den 14. april, den 23. maj og den 27. juni 1703.

Peter Knutsen blev medlem af skipperlavet i 1702. Hans skib "Håppet« (dvs. Hoffnung) var en 16 læster stor galiot. ${ }^{57}$ Han var skaffer i 1705 og omtales som død i $1708 .^{58}$

Der fandtes i 1704 to Sønderborg-skippere ved navn Andreas Krabbe, fader og søn, men ingen af dem synes på dette tidspunkt at have været medlem af lavet. Sønnen blev født i 1671. Senere blev han skipper, købmand og rådmand. I 1698 blev han gift med Anne Marie Hausvoigt, en steddatter til skipper Jürgen Löw. I 1718 registreredes han som medlem af lavet, 1739-40 var han skjørmand og 1740-43 oldermand. Han døde i $1743 .{ }^{59}$ En af de to Andreas Krabbe var »kirkeældste « i $1710 .{ }^{60}$ En af dem skulle også betale en bøde i 1695: »Andres Krabbe har slået Dettleff Baulunt et hul i hovedet med en lysestage. 


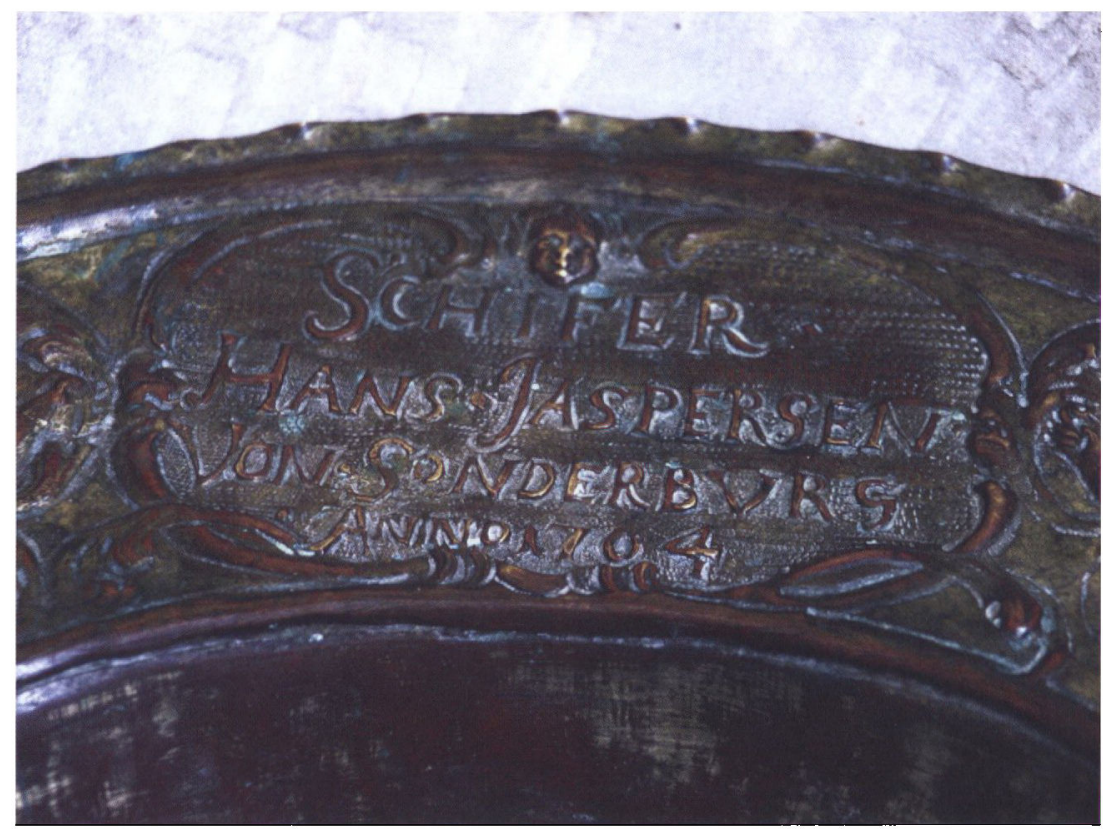

Dåbsfad i Helloi kirke (detalje). Foto: Jürgen Beyer.

Skal bøde 1 rigsdaler «. ${ }^{61}$ I 1708 optræder Andreas Krabbe igen i bøderegistret, men denne gang er det specificeret, at der er tale om den ældre: "Christian Callesen og den gamle Andreas Krabbe kom for nylig op at skændes ved en forlovelse, da de var berusede. De forligedes i retten, men Christian Callesen skal, som hovedmistænkt, bøde 3 mark lybsk «. ${ }^{62}$ Den 21 . april 1703 ville »Anders Krabbe hemma i Sönderborgh ... ifrån Hÿde till Kiöningbergh med sin Skuta Håppet, stoor 24. Läster «. ${ }^{63}$ Den 8 . juni sejlede han fra Lörje til Königsberg.

Hans Christian Krabbe var måske ikke medlem af skipperlavet, medmindre der snarere er tale om Christian Krabbe, der var medlem i 1681, men som senere måtte forlade lavet. En søn af en Hans Christian Krabbe, nemlig Christian Krabbe (født 1708), blev optaget i $1731 .{ }^{64} \mathrm{I}$ 1711 måtte faderen betale en bøde: »Hans Christian Krabbe ville heller ikke adlyde Nis Becker [opsynsmand ved skibbroen], sidste gang han lagde til « $\mathrm{i}$ havnen. ${ }^{65}$ Toldprotokollerne fra Visby kalder ejeren til en 24 læster stor galiot "Flygande fisken" snart Hans Krabbe, snart Hans Christian Krabbe. 
"Hans J: lasten" optræder i toldprotokollen som »Hans Jöran Lassen «, undtagelsesvis også i den tyske form »Hans Jürgen Lassen«. Hans skude »Sims(s)on « (også »Samsson «) var 21 læster stor. ${ }^{66}$ Han er nok den Hans Lassen, der blev medlem af skipperlavet i 1696. I 1703 blev han skaffer og i 1705 medlem af bestyrelsen. ${ }^{67}$

Christian Michelsen synes ikke at have været medlem af skipperlavet. Han sejlede med skuden "Maria", der var 14 læster stor.

Henning [N]ießen synes heller ikke at have været medlem af skipperlavet.

Eftersom der ved denne tid var mange skippere med fornavnet Lorenz, er $" L o r e n \beta »$ uden efternavn på pulpituret ikke nem at identificere. Toldprotokollerne fra 1703 nævner den 9. april »Lorents Christensson hemma i Sönderborgh, will ifrån Slijte till Kiöpenhamn med sin Kregert St. Johannes, stor 24 . Läster $«{ }^{68}$ Nogle uger senere, den 25. maj, sejlede han igen mellem Slite og København. Eftersom Slite ikke ligger i Hellvi Sogn, men længere sydpå, er dette nok ikke den Lorenz, vi leder efter. En bedre kandidat registreredes den 4. maj: »Lorentz Hansson Fisker hemma i Sönderborgh, will ifrån Kyllej till Wißmar med sin Skuta Tobias, stoor 22. Läster«. Den 3. juni optræder han igen, på vej fra Kyllaj til København. ${ }^{69}$ Den 23. maj nævnes dog også en "Lars Pärsson hemma i Sönderborg, will ifrån Wallewijk till Kiöpenhambn med sin Skuta S: Johannes stoor 24 . Läster «. ${ }^{70}$ Bag navnet Lars Pärsson kunne gemme sig en Lorenz Petersen.

De allerfleste af disse navne optræder også i en kollektbog fra 1703. Dengang blev der samlet penge ind til at istandsætte og udvide orglet i Sønderborg Kirke. ${ }^{71}$ Igen er det ikke muligt at identificere de ufuldstændige navne O.[?] Christensen og Lorenz, men følgende navne optræder: Christian Ahlman (betaler 3 mark lybsk), Michel Ahlman (2 mk.), Christian Hansen Fischer (1 mk., 8 skilling), ${ }^{72}$ Hanß Hanßen Schipfer (1 mk., 12 sk.) ${ }^{73}[\mathrm{~N}]$ is Ibßen (1 mk., 8 sk.), Christen Jürgenßen ( 2 mk., 8 sk.), ${ }^{74}$ Peter Knudzen ( 1 mk., 8 sk.), Andreas Krabbe (3 mk.), Hanß Christian Krabbe (3 mk.), Hanß Laßen (1 mk.) og Christian Michelsen (4 sk.).

Én af vore skippere fik ikke betalt. Blandt »Restanten « finder man Peter Andreßen (1 mk., $8 \mathrm{sk}$.). I samme afdeling står også »Andreaß Krab [sic] der Elter «, som skyldte 8 sk. Den mere velbeslåede Andreas Krabbe, der betalte $3 \mathrm{mk}$., er nok den, der blev født i 1671, og som senere blev oldermand for skipperlavet. Hvem af dem, der var med i Hellvi, er ikke til at afgøre. Endvidere manglede der penge fra Chri- 


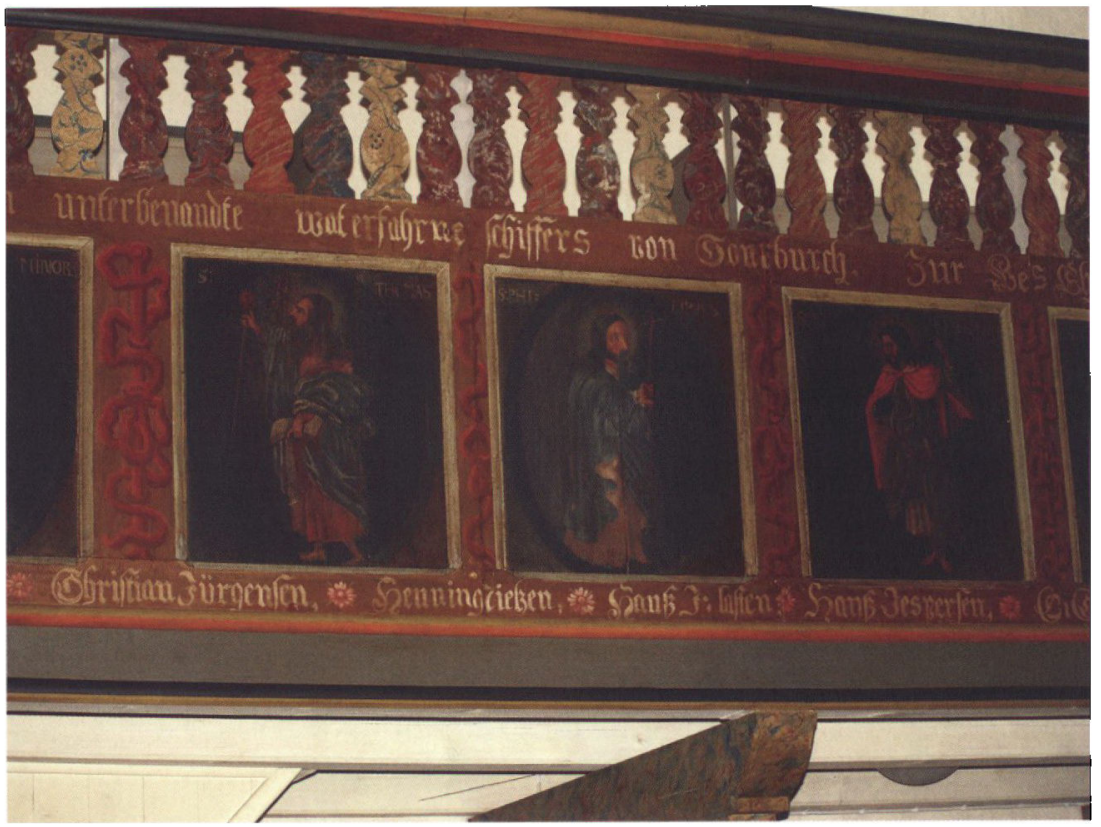

Pulpitur i Hellvi kirke (detalje). Foto: Jürgen Beyer.

stian Jürgensen, men eftersom der kun var tale om 4 sk., ${ }^{75}$ har vi nok her at gøre med en anden person end den, der lagde $2 \mathrm{mk}$., $8 \mathrm{sk}$. Af samme grund er den ovennæunte Christian Michelsen, der kun betalte 4 skilling, måske ikke én af vore skippere.

Beløbenes størrelse afspejler ikke givernes gavmildhed og forkærlighed for kirkemusik. Ikke mindst pga. afdelingen »Restanten« er der nok snarere tale om en mere eller mindre forpligtende ekstraskat, der afspejler ydeevnen. Nogle af de højere embedsmænd gav betydeligt mere, men skippernes beløb synes at svare til mange håndværkeres og er betydeligt højere end beløbene fra bådsmænd, daglejere og lignende, der kun gav et par skilling.

Om skipperne, der forærede bemalingen til Rute Kirke i 1730, kan oplyses meget mindre, da toldprotokollerne fra denne tid ikke er bevarede på Landsarkivet i Visby.

Jöns Jöranson Hophman synes at være identisk med den Jens Jürgen Hoffmann, der blev medlem af skipperlavet i 1733.

Hans Krabbe blev født i 1708 som søn af den ovenfor næunte Andre- 
as Krabbe (født i 1671), der muligvis er nævnt på pulpituret i Hellvi. Han var skipper, købmand og rådmand. I 1732 blev han optaget $i$ skipperlavet, og i 1741 var han medlem af bestyrelsen. Fra 1767 til 1772 beklædte han posten som skjørmand. Derefter tjente han som oldermand indtil 1776. Han døde samme år. Andreas Krabbe var gift to gange, først med Lorens Karbergs datter Cecilie, derefter med Katharina Petersen fra Tinglev. I 1739 betalte han en bøde på 8 skilling, fordi hans skorsten ikke var rengjort. ${ }^{76}$

Christian Höök synes ikke at have været medlem af skipperlavet og Matthias Rijper heller ikke. En "Christe[n] Höck" optræder ellers i 1703 i kollektbogen for orgelrenoveringen. ${ }^{77}$

\section{Pulpiturets historie og funktion i Hellvi Kirke}

I 1935 befandt denne bemalede trækonstruktion sig foran kirkeskibets vestlige væg og tjente som orgelpulpitur, men var tydeligvis blevet forandret, fordi det ikonografiske program var blevet udvidet med to figurer. Sveriges kyrkor skriver: »Läktaren torde, för en orgels skull, ha blivit utvidgad genom frambuktning av mittpartiet, troligen i slutet af 1700-talet eller omkr. 1800. Då måste också de båda ovannämnda helgonen ${ }^{78}$ målats, som nödvändig tillskarvning å bröstningen. Dessa två läktaremålningar synas tagit intryck av ryska ikoner «. ${ }^{79}$ Det ville have været et relativt tidligt orgel i en gotlandsk landsbykirke. Normalt havde de deres indtog først i 1800-tallet, og for Hellvi findes oplysning om, at orglet blev anskaffet i 1854. Pulpituret flyttedes i 1956 til dets nuværende placering ved skibets nordvæg. ${ }^{80}$ Under alle omstændigheder kan det fastslås, at hverken den nuværende placering eller den form, pulpituret havde i 1935, er originale. ${ }^{81}$

Pulpituret betegnes i indskriften som »Chor«. Ordet har desværre mange betydninger, og det er derfor ikke på forhånd givet, hvad trækonstruktionen oprindeligt blev brugt til. Også i Rute Kirke kan man læse ordet "kor", men et andet sted i kirken. I koret (dvs. kirkens østlige del) findes, hvad der er blevet betegnet som ryggen af en »korbänk" med følgende (ret ubehjælpsomt udseende) indskrift: »ANNO 1605 BLEF KOREN GIORD $\ll{ }^{82}$

Uden for Gotland kender man mest korstole som relikter af middelalderens gudstjenesteliv. Dengang var koret forbeholdt de gejstlige, og de sad eller stod i disse stole under gudstjenesten. Stole af denne type kendes også fra Gotlands middelalder. ${ }^{83}$ 
Efter reformationen medvirkede latinskoleeleverne som kirkesangere ved gudstjenesterne $\mathrm{i}$ de danske købstadskirker. I landsbyerne omkring købstæderne benyttede man sig af såkaldte løbedegne, dvs. latinskoleelever, der vandrede fra byen til landsbykirken og retur på samme dag. ${ }^{84}$ Gotland er dog kendetegnet ved, at der kun fandtes én købstad. De fleste sogne, inkl. Hellvi, ligger alt for langt fra Visby til at kunne engagere en løbedegn fra latinskolen. Derfor skabtes en anden institution til understøttelse af menighedens sang. Inden orglernes udbredelse i 1800-tallet anvendte man »korkarler «, dvs. mandlige menighedsmedlemmer med gode sangstemmer. De sad i en speciel kirkestol i koret (dvs. kirkens østlige del) og skulle synge så højt (og korrekt), at de kunne lede hele menighedens sang. Deres kirkestol blev kaldt »korbänk «. En sådan »korbänk« finder man den dag i dag i en del gotlandske kirker. ${ }^{85}$ Kirkerne i Sønderborg og omegn kendte derimod ikke til et sådant møbel. ${ }^{86}$

Ved tolkningen af indskriften fra Hellvi skal der dog også tages hensyn til sprogbrugen i Sonderborg, eftersom teksten er på tysk. For Sønderborg Kirke haves fortegnelser over stolestader fra 1783/84. Der nævnes en afdeling "Das Schiffer Chor", hvor bl.a. skipperne Ahlmann og Krabbe havde plads. ${ }^{87}$ Skipperkoret er ikke bevaret, og det er ikke helt klart, hvor det præcist lå, men der var åbenbart tale om et pulpitur, ${ }^{88}$ som betegnedes med ordet $\gg$ Chor «. ${ }^{89}$ Kirkens ældste fortegnelse over stolestader, påbegyndt i 1602, nævner ikke skipperkoret. Derimod indeholder den et tillæg med stolestader "på det høje kor på sydsiden «. I tillægget er det ældste årstal fra $1729,{ }^{90}$ men i de allerede nævnte fortegnelser fra 1783/84 finder man både året 1658 og året 1708 ved skipperkoret. Det er derfor muligt, at skipperkoret allerede eksisterede både fysisk og med denne betegnelse i 1704. Var konstruktionen i Hellvi oprindelig inspireret af forbilledet i Sønderborg? Men hvorfor betalte en anden for opførelsen og skipperne kun for »udstafferingen «? Pulpituret har i sin nuværende størrelse formentlig kunnet rumme besætningen af de Sønderborg-skibe, der plejede at ligge i Hellvi Sogns havne på samme tid. Pga. de omstændelige toldformaliteter havde skibene mange liggedage, og derfor tilbragte man nok ikke så få sondage på Gotland.

Skipperne fra Sønderborg var hjemmefra vant til et orgel i kirken, men det var jo også en bykirke. Orglet i Sønderborg Kirke omtales første gang i 1604, da man begyndte at bygge et nyt orgel. ${ }^{91}$ Det er usandsynligt, at pulpituret i Hellvi Kirke blev bygget for et orgels 
skyld. Et orgel nævnes først i 1854, og så blev det eksisterende pulpitur dengang åbenbart udvidet for at rumme instrumentet (se ovenfor).

Giver sognets arkivalier måske svar på disse spørgsmål? Hellvi Kirkes inventarfortegnelse fra 1739 nævner kun bevægelige og ikke faste ejendele, ${ }^{92}$ men i kirkeregnskabet for 1703 findes et par poster, der står $i$ forbindelse med en omfattende fornyelse af kirkens indre ved denne tid:

»Monsr: Anders Fries förärt til Helwigs Kÿrkia en altartafla af Bursw[i]kz sten för

50.

Monsr: Schilder en nÿ funt

10.

Monsr: Erick Bähr et ${ }^{93}$ nÿt Choer med et bord uthi och en ${ }^{94}$ benk

Kÿrkiowerjaren Tomas Längers förärt et nyt skåp i koret med låås före

Morten Sudergård

2.

Ofwanstående föräringar komma intet med uti Kyrkiones räkenskap, emädan the äntå komma skulle til at afföres i utgiften; utan stå elliest her til en åminnelse upskrefne. « ${ }^{95}$

Alligevel synes disse indkomster summarisk at være opført under »Kyrkans utgifter« lidt senere:

»forskutit til kyrkiobÿnaden [sic] tilsammen som listan utwjsat

Der blev altså anskaffet ny altertavle, døbefont, skab og »Choer « (dvs. "korbänk «). ${ }^{97}$ De nævnte genstande befinder sig endnu i kirken. Familierne Fries, Schilder og Bähr, der stod for de større gaver, ejede kalkbrænderier i Hellvi Sogn. ${ }^{98}$

Skipperne fra Sønderborg nævnes ikke med ét ord. Deres gaver kom som naturalier, og beløbene behøvede derfor ikke bogføres i regnskaberne over kirkens indtægter og udgifter. Eftersom de andre givere nævnes i regnskabsbogen "til en åminnelse«, kan man undre sig over, hvorfor skipperne ikke omtales. Måske er den simple grund den, at de selv sørgede for, at deres navne blev husket ved at skrive dem tydeligt på gaverne?

Indskriften på pulpituret siger, at skipperne lod koret »udstaffere«. 


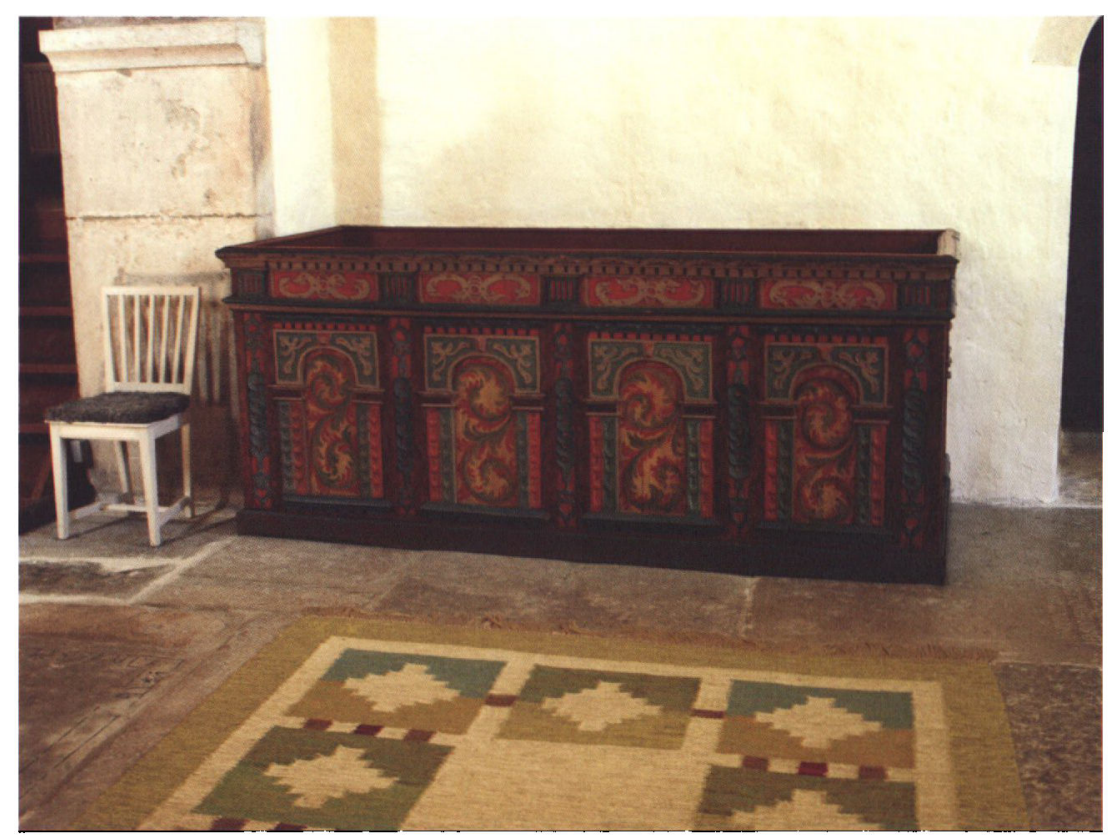

»Korbänk« $i$ Hellvi kirke. Foto: Jürgen Beyer.

De lod det altså ikke bygge, men blot male. En lignende indskrift kendte skipperne sikkert fra Sønderborg Kirke, hvor man kunne læse på prædikestolen: »Apotekeren Johannes Willers har ladet udstaffere dette på nyt i 1692 «.99 $^{99}$

Malingen af pulpituret tilskrives Christian Lorentz Numens. ${ }^{100}$ Han var født $i$ Tønder i 1671. Senest 1701 flyttede han til Visby, hvor han giftede sig med datteren af en juridisk embedsmand. Det følgende år blev han borger $\mathrm{i}$ Visby. Ægtefællerne, som havde fået tre sønner, døde af pesten i $1711 .{ }^{101}$

Forlæggene til billederne på pulpituret har kunnet identificeres. De går tilbage til kobberstik af brødrene Wierix. ${ }^{102}$ Ved andre lejligheder producerede Numens også indskrifter på svensk. ${ }^{103}$ Hvorfor skrev han i Hellvi på højtysk (med visse plattyske indslag)? Var det bestillernes ønske? Under alle omstændigheder var det et sprog, som både kunstneren og opdragsgiverne var fortrolige med - inklusive de plattyske indslag. Desværre kan dette ikke påvises $\mathrm{i}$ andre tekster fra Numens' hånd. Godt nok findes der en henvendelse af Numens til 
byrådet i Visby, modtaget den 11. marts 1701, men den er affattet på svensk og er i øvrigt ikke egenhændigt. ${ }^{104}$

\section{Panelets historie og funktion i Rute Kirke}

Træpanelet fra 1730 tjente endnu i 1935 som skillevæg mellem tårnrummet og skibet. ${ }^{105}$ Det var meget almindeligt på Gotland i tiden efter reformationen, at tårnrummet blev adskilt og brugt som lagerrum til alskens ting. ${ }^{106} \mathrm{Nu}$ er tårnrummene i de fleste kirker blevet inddraget $i$ kirkerummet, fordi den middelalderlige tilstand langt hen ad vejen har været målet ved restaureringer. Træpanelet i Rute Kirke synes at være et af de få, der fortsat findes i kirken, omend ikke på sin oprindelige plads. Indskriften oplyser - som i Hellvi - at skipperne stod for bemalingen. Det er ukendt, hvem der lod skillevæggen bygge, og hvornår det skete.

\section{Skippernes sprog}

Siger indskrifterne noget om det sprog, skipperne fra Sønderborg talte? Indskriften på panelet $\mathrm{i}$ Rute Kirke er på svensk. Muligvis kunne skipperne tale en slags "tillämpad danska« til brug i Sverige, men givetvis var svensk ikke noget sprog, de talte til dagligt. Denne indskrift blev nok formuleret af en gotlænder.

Vanskeligere er det med indskriften fra Hellvi. Heller ikke her kan det udelukkes, at tekstens endelige form stammer fra en person på Gotland, f.eks. den i Tønder fødte maler Numens. Indskriften er på højtysk med enkelte ejendommeligheder, der tyder på plattysk indflydelse (som flertalsformen Schiffers). I arkivalier fra Sønderborg finder man plattyske tekster endnu ret sent, i hele første halvdel af 1600-tallet, men derefter skifter man også i Sønderborg til højtysk. ${ }^{107}$

Mens det er nemt at se, hvilket sprog der bliver anvendt på skrift, er det straks sværere med det talte sprog. I forste tredjedel af $1700-$ tallet taltes i Sønderborg sønderjysk, plattysk, højtysk og muligvis rigsdansk, mens der blev skrevet højtysk (og privat måske også rigsdansk). Mange beboere var flersprogede eller forstod de sprog, de kun delvis eller slet ikke talte selv, men der fandtes også folk, der ikke kunne forstå visse sprog overhovedet. Sprogkundskaberne var bl.a. afhængige af en persons sociale position (de højere sociale lag havde en tendens til højtysk, de lavere til sønderjysk). Selvfølgelig 
spillede det også ind, i hvilken egn eller landsdel en beboer var opvokset. $^{108}$

Ved en udredning om indførelse af dansk forvaltningssprog i Sønderborg og Nordborg Amter blev det konkluderet i 1811 - altså hundrede år senere - at landområdet havde dansk skole- og kirkesprog, men at det øvrige forvaltningssprog var tysk. Flere ting talte imod indførelsen af dansk forvaltningssprog: Den gældende tysksprogede lovgivning adskilte sig fra den rigsdanske, og et sprogskifte ville medføre terminologiske vanskeligheder. De fleste embedsmænd beherskede ikke dansk skriftligt, selv i de tilfælde, hvor de kunne klare sig mundtligt. I Sønderborg prædikede sognepræsten og andenpræsten tysk, tredjepræsten dansk. Skoleundervisningen foregik på tysk, men der blev også givet dansktimer. De fleste skolelærere ville ikke kunne undervise på dansk. Det anbefaledes at bibeholde tysk kirkesprog i Sønderborg, fordi en del håndværkere ikke ville kunne forstå en dansk prædiken, og en del »Beamte und andere Honoratioren « var mere vante til at bruge tysk end dansk. ${ }^{109}$

Dette siger desværre ikke meget om skippernes sprogforhold og endnu mindre om forholdene hundrede år tidligere. Fra endnu senere haves en trykt visebog for skipperlavet i flere oplag. Første gang den blev trykt, var sandsynligvis i 1888. Et lille flertal af viserne er på rigsdansk; de øvrige sange er på højtysk. ${ }^{110}$ Men i 1888 er vi kommet ind $\mathrm{i}$ en ny tid: tiden for de nationale stridigheder og for indflytningen af den sønderjysktalende landbefolkning til byen. Skipperlavets ældste protokolbog, der dækker tiden fra 1681 til 1831, er udelukkende ført på højtysk. Det afspejler dog ikke nødvendigvis mere end oldermandens og skjørmandens skriftlige sprogbrug.

Hvad angår skipperne fra 1704 og 1730, så er det sandsynligt, at de talte både plattysk og sønderjysk, kunne læse højtysk og rigsdansk og skrev på højtysk, selvom der kunne findes aftryk af andre sprog i det skriftlige (som formen Schiffers vidner om) - for slet ikke at tale om det mundtlige. ${ }^{111}$

Pulpituret og dåbsfadet var ikke de første inventarstykker med tyske indskrifter i Hellvi Kirke. Sådanne findes nemlig også på Lars Mattssons epitafium i koret. ${ }^{112}$ Dateringen lyder godt nok på 1726, men ved dette tidspunkt var epitafiet blevet genanvendt af Mattsons søn og svigerdatter. På Mattsons gravsten, der i øvrigt er affattet på dansk med visse svenske indslag, kan man læse, at han døde den 25. januar 1671 efter at have været havnefoged i Hellvi og senere rådsstueskriver og 
rådmand $\mathrm{i}$ Visby, men der siges intet om, at han også ejede et kalkbrænderi i Hellvi Sogn. ${ }^{113}$ Den tyske indskrift på pulpituret virkede derfor måske ikke helt så fremmed, som man kunne være fristet til at tro.

\section{Skippernes motiver}

Udenlandske skippere har efterladt deres spor også andre steder på Gotland. I Gotlands kyrkors beskrivelse af Fröjel Kirke står: "Säve såg, 1864, två bänkstolpar, varå var målat 'Diie Rostockers' och 'Skippers 1638', samt en tredje dylik skadad inskr[ift], en erinring om äldre tiders handel i Fröjels hamn. Rostockskepparna hade tydligen egen bänk (jfr. Sönderborgskepparnas läktare och fat i Hellvi kyrka i Bd II, s. 122) «. ${ }^{114}$ Åbenbart mente forfatterne, at pulpituret i Hellvi var tænkt som siddeplads for skipperne fra Sønderborg. ${ }^{115}$ Det er muligt, men dåbsfadet var næppe forbeholdt skippernes børn.

Der er også blevet fremført andre formodninger om årsagen til donationerne. De 16 skippere fra Sønderborg skulle således have været bosat ved Kyllaj og købt sig stolestader i Hellvi Kirke. ${ }^{116}$ Pulpituret anses også at være »till minne av deras räddning (de skänkte även locket till dopfunten)« ${ }^{117}$ Dette er allerede usandsynligt af den grund, at hver af skipperne må antages at have sejlet på eget skib. Der ville have været tale om en af de større ulykker i gotlandsk søfartshistorie, men det har ellers ikke efterladt sig spor i kilderne.

En mulig forklaring på gaverne kunne være, at skipperne var blevet overrasket af tidlig frost og derfor tvunget til at tilbringe vinteren i Hellvi. I så fald ville de dog alle sammen være sejlet som nogle af de forste $i$ det følgende forår og dermed have fyldt massivt $i$ toldprotokollens begyndelse. Det er ikke tilfældet, og derfor kan denne hypotese aflives.

Også angående træpanelet i Rute Kirke er det blevet påstået, at de fire Sønderborgere havde lidt skibbrud ved Gotland. ${ }^{118}$ Det er lige så usandsynligt som i Hellvi. ${ }^{119}$

De fleste af vore skippere gav pænt til et nyt orgel i Sønderborg, da det blev forventet af dem. Derimod optræder de ikke i donationsbogen for Sønderborg Kirke (som i øvrigt ikke synes at have fået alle gaver med). Hvorfor var de mere gavmilde i udlandet end hjemme?

På skibene fandtes fattigbøsser, hvis indhold hvert år skulle afleveres til skipperlavet. ${ }^{120}$ Nøglerne blev opbevaret hos oldermanden. Der blev lagt penge i bøsserne ved særlige lejligheder, f.eks. ved over- 
stået havsnød eller når sømænd fik hyre. I 1682 blev der fastsat et bødebeløb på én rigsdaler, hvis en skipper undlod at aflevere fattigbøssens indhold, og i 1703 blev det indskærpet, at fattigbøsserne skulle afleveres straks efter hjemkomsten. Af det samlede beløb blev som regel omtrent halvdelen givet til de fattige. ${ }^{121}$ Også i Hellvi Kirkes regnskaber kan man en sjelden gang se pengegaver fra skippere noteret, bl.a. fra Sønderborg. ${ }^{122}$ Man kan i det mindste fastholde, at skipperne var vant til at give til velgørende formål. I Sønderborg skete det dog i skipperlavets navn; skipperne fremstod ikke personligt.

En direkte begrundelse for udsmykningen af pulpituret kan desværre ikke findes i kilderne. Den mest sandsynlige forklaring er, at skipperne gennem flere år var sejlet på havne i Hellvi Sogn. Da sognet gennemførte en omfattende fornyelse af kirkens inventar, ville man vise sin erkendtlighed ved at forære bemalingen og dåbsfadet.

Hvis man vidste, hvem der betalte for opførelsen af pulpituret, kunne man måske sige mere om dets oprindelse og anvendelse. Hvor mange år inden bemalingen blev pulpituret bygget? Blev pulpituret bygget for at råde bod på pladsmangelen, som det skete mange steder i 1700- og 1800-tallet? ${ }^{123}$ I så fald ville initiativet nok være kommet fra sognet. Eller var anledningen standsbevidsthed? Så kunne det have været skipperne, der kom med forslaget om et skipperkor som i Sønderborg. ${ }^{124}$ I dette tilfælde ville pulpituret have tjent som siddeplads for skipperne, men mon de havde bedt om en bedre placering end kirkeskibets vestmur? Der kan også spekuleres over, om skibenes besætninger fik lov til at sidde på pulpituret, eller om de måtte finde sig en mindre fremtrædende plads nede i kirken. Muligvis slog skippere fra flere byer sig sammen for at betale for opførelsen, mens sønderborgerne var så smarte at betale for bemalingen. På denne måde fik de deres navne fastholdt for eftertiden.

I denne artikel har det alene været hensigten at behandle de sønderborgske gaver $\mathrm{i}$ to gotlandske kirker. Afslutningsvis er der dog grund til at rejse spørgsmålet om, hvorvidt sådanne gaver fra fremmede var almindelige ved denne tid. Der synes at mangle forskning på området, men følgende hovedlinjer kan vist ridses op.

Selv om lutherdommen grundlæggende var organiseret territorielt - enhver tilhørte det sogn, han boede i - så måtte man finde praktiske løsninger til de mange folk, der var omrejsende, eller som bosatte sig i udlandet, hvor der blev prædiket på et andet sprog. Når tilstrækkeligt mange fremmedsprogede boede permanent i en by, blev 
der aflønnet en præst til at prædike på deres sprog i en af de eksisterende kirker, eller der blev indrettet en speciel kirke for den fremmedsprogede menighed. ${ }^{125}$

Når de fremmedes antal ikke var så stort, eller hvis de kun kom periodisk, kunne der være tale om, at bestemte stolestader reserveredes til dem, eller at de ved forskellige lejligheder forærede gaver til kirken, eftersom de ikke betalte tiende. ${ }^{26}$ Det er formentlig det sidste, vi finder eksempler på i Hellvi og Rute Kirker.

\section{NOTER}

1. Artiklen er en omskrevet udgave af Jürgen Beyer: "Gaver fra Sønderborg-skippere til kirkerne i Hellvi og Rute« i Per Stobaeus (red.): Kust och kyrka på Gotland. Historiska uppsatser (=Arkiv på Gotland, bd. 7), Visby 2010 , s. 365-386, hvor der findes et mere udførligt noteapparat, bl.a. med præcise henvisninger til toldprotokollerne fra Visby. Jeg takker oldermanden for Senderborg Skipperlaug, Henning Bach, for adgang til sit store materiale om skipperlavets historie og for den venlige modtagelse i Sønderborg. Han gav desuden tilladelse til, at jeg kunne konsultere skipperlavets protokolbog på Det Kgl. Bibliotek i København. Ellers er den deponeret, som hele skipperlavets arkiv, på Museet på Sønderborg Slot. Jeg takker også Inge Adriansen og Ivan Boserup for at have organiseret indlånet mellem deres institutioner og Charlotte Appel (Roskilde) for at have korrigeret mit dansk. Ligeledes vil jeg gerne takke Tryggve Siltberg (Visby) for henvisningerne til indskrifter $i$ Fröjel og Rute Kirker og mange gode råd ang. Gotlands historie samt Anders R. Johansson (Hellvi) og Magnus Ressel (Bochum) for kommentarer. Endvidere skal der rettes tak for finansiel understottelse til Carlsbergfondet, Det Letterstedtske Selskab og projektgruppen SF0180040s08 ved Tartu Universitetsbibliotek.

2. Sveriges kyrkor. Konsthistoriskt inventarium. Gotland, bd. 1ff., Stockholm 1931ff., her bd. 2, s. 42, 120-122; Louis E. Grandjean og Knud E. Hansen: De danske Gotlandsfarere (=Søhistoriske skrifter, bd. 4), Visby og Kobenhavn 1950, s. 68; Gunnar Svahnström og Karin Svahnström: Måleri på Gotland 1530-1830, Visby 1989, s. 149, 153; Anders R. Johansson, Karin Felderman og Carl Franzén: Hellvitrakten. Platser och historik $A-O ̈$..., [Lärbro] 2000 , s. 154.

3. Landsarkivet i Visby: Visby tullkammares arkiv, G VII: 7: Räkenskaper utgående journaler 1701-1705 (upagineret), årg. 1703 (i det følgende forkortet som "Udgående toldprotokoller Visby «). Tallet 342 er det sidste i nummereringen. Det skal tages med et vist forbehold, da der forekommer enkelte skibe uden for nummereringen, frem for alt dem, der sejlede inden for Sveriges grænser. Antallet af afgange er ikke det samme som antallet af skibe. Mange skippere besøgte Gotland flere gange om året.

4. H[enning] Bach: Sønderborg Skipperlaug's historie, [Sønderborg 2005], s. $21 \mathrm{f}$.

5. Om skipperlavet, se Paul Egon Döring: "Das Schiffergelag in Sonderburg. Nach den in der Gelagslade vorhandenen Urkunden « $\mathrm{i}$ Zeitschrift der Gesellschaft für Schleswig-Holstein-Lauenburgische Geschichte 26 (1896), s. 413- 
468; J[ens] Raben: Sonderborg Skipperlaug og et Brudstykke af Byens Søfartshistorie (=Fra Als og Sundeved, bd. 8), Sønderborg 1934; Jens Raben: „Sø og havn « i Robert Huhle (red.): Bogen om Als, Aabenraa 1956, s. 231-268; J[ens] Raben: "Glimt fra gamle dages søfart" i Fra Als og Sundeved 40 (1961), s. 66-68; Niels Knudsen: Sonderborg Skipperlaug 1571-1971 (=Fra Als og Sundeved, bd. 49), Sonderborg 1970; Bach: Sonderborg Skipperlaug's historie (jf. n. 4). Skipperlav fandtes også i andre havnebyer.

6. Rettelig: untenbenandte.

7. Rettelig: wolerfahrne.

8. Rettelig: Schiffer.

9. Sonderburch.

10. Sandsynligvis: Gottes.

11. kirchen. $h$ 'ets højre ben stammer vist fra $n^{\prime}$ et.

12. Noget udvisket, oprindeligt givetvis ihres.

13. gedächtnis.

14. Staffieren.

15. ANNO.

16. Tegnet gengiver en blomst, som anvendes på pulpituret til at markere begyndelsen af et navn.

17. Muligvis er der snarere tale om $C$.

18. Christian.

19. Andreas.

20. Christian.

21. Christian.

22. Nogle navne er blevet kompletteret efter toldprotokollerne fra Visby (se nedenfor).

23. Jf. Sveriges kyrkor. Gotland (jf. n. 2), bd. 2, s. 122 (med lettere læsefejl).

24. Desværre kunne jeg kun arbejde i begrænset tid på Landsarkivet i Visby. Jeg nåede at se de udgående toldprotokoller for tiden 1. januar til 27. juni 1703 meget grundigt igennem (180 afgange). I de andre toldprotokoller, også de indgående, kunne jeg kun gøre stikprøver. Toldprotokollerne er uden registre, men sådanne var heller ikke nødvendige, for at journalerne kunne tjene deres oprindelige formål.

25. Jf. Åke G. Sjöberg: „Gotländska tulljournaler. En förbisedd källa inom östersöfartens historia. Studier kring gotländska tulljournaler 1647-
1660« i Gotländska studier 5 (1977), s. 27-43, her s. $28 \mathrm{f} ., 43$.

26. Sjöberg: Gotländska tulljournaler (jf. n. 25), s. 29f. En instruktion fra 1724 indeholder stort set uændrede bestemmelser (aftrykt i Anders Emilsson og Ingvar Kavonius: Livet kring kalk och sten $i$ Helloi under 300 år, [Lärbro] 1997, s. 76f.).

27. Sveriges kyrkor. Gotland (jf. n. 2), bd. 2, s. 40; jf. Tommy Sundberg: »Summarisk förteckning över de gotländska kyrkoarkiven « i Sten Körner, Tryggve Siltberg og Tommy Sundberg: Arkivforskning pi Gotland (= Gotlandica, bd. 16), Visby 1979, s. $12-$ 68, her s. 58.

28. Jf. også Robert Bohn: Das Handelshaus Donner in Visby und der gotländische Außsenthandel im 18. Jahrlundert. Eine Studie zur Handels- und Seefahrtsgeschichte des Ostsecraums im Spätmerkantilismus (=Quellen und Darstellungen zur hansischen Geschichte, N. F., bd. 33), Köln og Wien 1989, s. 59, tabel 7; Sven Gerentz: »Gotländsk sjöfart på 1680-talet« i Gotländskt arkiv 64 (1992), s. 187-194.

29. Henr[ik] Munthe: "Ur den gotländska kalkindustriens historia " i Med hammare och fackla 13 (1943-44), s. 1135; Arvid Ohlsson: Gotlands kalkpatroner. En berättelse om Gotlands kalkbruksindustri, Visby 1964; Emilsson/ Kavonius: Livet kring kalk och sten $i$ Hellvi (jf. n. 26).

30. Jf. også Emilsson/Kavonius: Livet kring kalk och sten $i$ Hellvi (jf. n. 26), s. 59.

31. Jf. også Bohn: Das Handelshaus Donner (jf. n. 28), s. 99-101. Isdækket var formentlig ikke den eneste faktor, der havde indflydelse på vinterpausen, men det er muligt, at toldprotokollerne også vil kunne bruges i den klimahistoriske forskning.

32. Vallevik ligger i dag i Rute Sogn, men havnen hørte omkring 1700 til Hellvi Sogn. Ved denne tid betegnes havnen som 7-9 fod dyb. Värne havn havde 7,5 fod, Lörje og Kyllaj 9-10 fod og Hide 10-11 fod (Johansson/ Felderman/Franzén: Hellvitrakten (jf. n. 2), s. 86f., 144, 187, 311f., 327 og kortet bag på indbindingen). 
33. Bohn: Das Handelshaus Donner (jf. $\mathrm{n}$. 28), s. 59 , tabel 7.

34. F. eks. "Hemming Hembken ... med sin Skuta Enigheet stor 20: Läster« (Udgående toldprotokoller Visby 1703 (jf. n. 3), nr. 22 (16. april) - den 3. juni (nr. 128) hed skuden med samme lasteevne "Elephanten «); »Nils Petterson Becker ... med sin Skuta Håppet stoor 18. Läster« (sst., nr. 45 (27. april) (citat); nr. 158 (15. juni)); »Christian Assmusson ... med sin Kregert Gideon, stor 20. Läster" (sst., nr. 63 (4. maj)); "Christian Rassmusson ... med sin Kregert Gideon, stoor 20. Läster « (sst., nr. 159 (15. juni)). Asmussen (nr. 63) er nok den samme som Rasmussen (nr. 159), fordi de har samme fornavn og skib.

35. Ikke blot ved de hyppige navne på -sen, men også når slægtninge har samme fornavn kan der forekomme forvekslinger. Desuden findes der åbenbart en del fejl i toldprotokollerne (jf. n. 34).

36. Museet på Sønderborg Slot: Sønderborg Skipperlaug, nr. 126: Protokolbog (1681-1831).

37. Inge Adriansen: "Sonderburg. Eine Stadt im Grenzland zwischen Dänisch und Deutsch « i Schriften der Heimatkundlichen Arbeitsgenteinschaft fiir Nordschleswig 81 (2006), s. 9-78, her s. 15.

38. Protokolbog (jf. n. 36), fol. 6r (en anden hånd har tilføjet "todt« efter hans navn), 10v, 24r; Gustaf Ahlmann: Släktregister Ahlmann, Borlänge 1967, s. 10; C. J. Andersen: »Slægten Ahlmann. Af en alsisk slægts historie« i [Hans Krogh et al. (red.):] Jens Raben, 14. marts 1880-18. februar 1960, Sønderborg 1960, s. 13-26, her s. 21.

39. Stammbuch der Familie Ahlmann. Gravensteiner Linie, Kiel 1917, s. 1; Stammtafel des Geschlechts Ahlmann. Gravensteiner Linie, Görlitz [efter 1927]; Knudsen: Sønderborg Skipperlaug (jf. n. 5), s. 112. Disse værker udviser visse uoverensstemmelser i de biografiske detailjer.

40. Protokolbog (jf. n. 36), fol. 5v, 10r, 19r, 25r, 27r, 31r, 39r, 50v; Döring: Das Schiffergelag (jf. n. 5), s. 448; Raben:
Sønderborg Skipperlaug (jf. n. 5), s. 16.

41. Protokolbog (if. n. 36), fol. 32r, 59r, 61v. De ledende embeder i skipperlavet var folgende: $\ddot{\text { lltermand }}$ (oldermand, formand), Scheurmann (skjørmand, næestformand), fire beisitzende Älteste (bestyrelsesmedlemmer) og fire (senere to) Schaffer (skaffere); jf. også Döring: Das Schifferge$\operatorname{lag}$ (jf. n. 5), s. 428.

42. Jf. Martin Rheinheimer: Der fremde Sohn. Hark Olufs' Wiederkehr aus der Sklaverei (=Nordfriesische Quellen und Studien, bd. 3), Neumünster 2003; Knudsen: Sonderborg Skipperlaug (jf. n. 5), s. 81; Das Flensburger Schiffergelag in Vergangenheit und $\mathrm{Ge}$ gcnwart (= Kleine Reihe der Gesellschaft für Flensburger Stadtgeschichte, bd. 3), Flensborg 1979, s. 72-74; Arthur G. Hasse: Københavns Skipperlav 1634-1934, Kobenhavn 1934, s. 81-83; jf. også Magnus Ressels kommende ph.d.-afhandling ved Bochums Universitet.

43. Protokolbog (jf. n. 36), fol. 43v: "NB $\mathrm{Zu}$ Ranzionirung des in der Barbarischen Schlaverey sich leÿder anitzo befindenden Bürgers v: Schiffer Michel Ahlmans alß Gelagsbrudern, ist, von dem Löbl. Gelage beliebet worden $50 \mathrm{~m}$ [ark]".

44. Protokolbog (jf. n. 36), fol. 43r, 47r, 49r.

45. Protokolbog (jf. n. 36), fol. 95r, 96v. Ordet sk(j)ermand optræder kun i Sonderborg. Dets tyske modstykke i skipperlavets arkivalier er Scheurmann. Begge ord findes ikke i de gængse ordboger. Én mulighed ville være at forbinde ordet med nedertysk schanen 'die Aufsicht über etwas haben' (Otto Mensing: Schleswig-Holsteinisches Wörterbuch, bd. 4, Neumünster 1933, sp. 299f.), en anden med det jyske skärsmand, der betegnede en medhjælper af oldermanden (H[enning] F[rederik] Feilberg: Bidrag til en Ordbog over jyske Almuesmal, bd. 1-4, Kobenhavn 1886-1914, her bd. 3, s. 355).

46. Stammtafel (jf. n. 39); Knudsen: Senderborg Skipperlaug (jf. n. 5), s. 112; Stammbuch (jf. n. 39), s. 1; Andersen: Slægten Ahlmann (jf. n. 38), s. 14; Ahl- 
mann: Släktregister Ahlmann (jf. n. 38), s. 9 (de tre sidste værker daterer døden til 1734).

47. Om beregningsgrundlaget for læsterne, se Åke G. Sjöberg: "Fartygslästen. En undersökning av lästen som fartygsmått $i$ de gotländska hamnarna 1630-1660« i Gotländska studier 5 (1977), s. 44-77. Skibstypen krejert kaldes i de svensksprogede toldprotokoller for "Kregert". Ordbok öfver svenska språket utgifven af Svenska Akademien, bd. 1ff., Lund 1898ff., her bd. 15, 1939, sp. K 2699 , nævner som normaliseret form $\mathrm{Kre}$ jare og desuden mange varianter, men ingen af dem ender på - $t$. Det synes at være en dansk ejendommelighed!

48. Protokolbog (jf. n. 36), fol. 99r; Landsarkivet i Aabenraa: Kommunale arkiver, Sønderborg købstad -1869, 96a: Bøderegister 1633-1820, årg. 1700 (upagineret).

49. I toldprotokollerne bruges ordet "Skuta«, jf. Ordbok öfver svenska sprìket (jf. n. 47), bd. 27, sp. S5379. Ifølge Sjöberg: Gotländska tulljournaler (jf. n. 25), s. 37, dækker ordet skuta i toldprotokollerne over flere forskellige skibstyper.

50. Döring: Das Schiffergelag (jf. n. 5), s. 433. Efternavnet Christensen derimod optræder $i$ skipperlavet ved denne tid, f. eks. Knut Christensen (blev medlem i 1705) og Lorenz Christensen (medlem af bestyrelsen i 1705) (Protokolbog (jf. n. 36), fol. 94r f.).

51. Protokolbog (jf. n. 36), fol. 94v; Knudsen: Sonderborg Skipperlaug (jf. n. 5), s. 81 (desværre udateret).

52. Protokolbog (jf. n. 36), fol. 99r; Sønderborg Bøderegister mortensdag 1710 til mortensdag 1711 (jf. n. 48) (upagineret): "Hans Hansen hat Anna Jürgens hier in der Statt geschwängert, nach dem es aber rüchtbahr, haben sie sich (nach gele[i]steter Caution) auf dem [sic] Lande begeben, und daselbst verlobet worden." - - - "gibt ad pias causas".

53. Protokolbog (jf. n. 36), fol. 88v, $102 \mathrm{v}$.

54. Protokolbog (jf. n. 36), fol. 6v, 67r, 72v, 82v; LA Aabenraa: Sønderborg præstearkiv, nr. Ca 1: Kirkeregnskabsbog 1554-1733, fol. 57r: "Kirchgeschworne[r]«.

55. Protokolbog (jf. n. 36), fol. 71r, 77v, 94r.

56. Sonderborg Bøderegister mortensdag 1709 til mortensdag 1710 (jf. $n$. 48), s. 3. J[ens] Raben: "Sønderborgskippere og byens retsvæesen " i Fra Als og Sundeved 40 (1961), s. 34-37, her s. 34, nævner denne sag med årstallet 1701 .

57. Skibstypen kaldes i toldprotokollerne "Galliort", på moderne svensk galliot (jf. Ordbok öfver svenska språket (jf. n. 47), bd. 10, 1929, sp. G 58).

58. Protokolbog (jf. n. 36), fol. 83r, 94r, $102 \mathrm{v}$.

59. Protokolbog (if. n. 36), fol. 106v, 123r; Knudsen: Senderborg Skipperlaug (jf. n. 5), s. 115, 120; Olaf Lassen: "Sønderborg Skipperlaug og dets oldermænd “ i [Hans Krogh et al. (red.):] Jens Raben, 14. marts 1880-18. februar 1960, Sonderborg 1960, s. 104-110, her s. 107.

60. Kirkeregnskabsbog Sonderborg (jf. n. 54), fol. 57r: "Kirchgeschworne[r]«.

61. Sønderborg Bøderegister 1695 (jf. $n$. 48) (upagineret): "Andres Krabbe hat Dettleff Baulunt mit ein [sic] Leüchter ein [sic] Wunde im [sic] Kopf geschlagen soll Brüchen 1 R[eichsthale]r."

62. Sønderborg Bøderegister mortensdag 1707 til mortensdag 1708 (jf. $n$. 48) (upagineret): "Christian Callesen vnd der alte Andreas Krabbe, seint ohnlangsthin auf einer Verlöbnüß bey trunckenem Muhte in Zwistigkeit mit einander gerahten, haben sich aber vor Gericht vertragen, doch soll Christian Callesen auf den [sic] der meiste Verdacht haftet, dafür auf dingen, Brüche 3 [Mark lübsch] «.

63. Udgående toldprotokoller Visby 1703 (jf. n. 3), nr. 33

64. Protokolbog (jf. n. 36), fol. 6r, 117r.

65. Senderborg Berderegister mortensdag 1710 - mortensdag 1711 (jf. n. 48) (upagineret): "Hans Christian Krabbe hat ebenfals Beÿ seiner Letz- 
ten ankunfft Nis Beckern nicht pariren wollen «.

66. Landsarkivet i Visby: Visby tullkammares arkiv, G II: 9: Räkenskaper inkomna journaler 1701-1705 (upagineret), årg. 1701, nr. 22 (17. april), nr. 86 (24. maj), nr. 280 (17. aug.); Udgående toldprotokoller Visby 1701 (jf. n. 7), nr. 20 (17. april).

67. Protokolbog (jf. n. 36), fol. 74r, 82v, $94 \mathrm{v}$.

68. Udgånde toldprotokoller Visby 1703 (jf. n. 3), nr. 10.

69. Udgående toldprotokoller Visby 1703 (jf. n. 3), nr. 62, 129.

70. Udgående toldprotokoller Visby 1703 (jf. n. 3), nr. 86.

71. Landsarkivet i Aabenraa: Sønderborg præstearkiv, nr. H 6: Kollektbog for reparation og udvidelse af orglet 1703, fol. $8 \mathrm{r}, 10 \mathrm{v}$ f., 12v, 16r f., $17 \mathrm{v}, 19 \mathrm{v}, 20 \mathrm{v}$ f., $23 \mathrm{r}, 24 \mathrm{r}$. De fleste indforsler er dateret 18 . oktober. Navnene er skrevet med forskellige hænder, men ikke således, at hvert navn er skrevet med en anden hånd. Der er sandsynligvis ikke tale om egenhændige navnetræk. Navnene gengives $i$ det folgende med den originale retskrivning.

72. Der gik 16 skilling til én mark (Klaus-Joachim Lorenzen-Schmidt: Kleines Lexikon alter schleswig-holsteinischer Gewichte, Mafse und Währungseinheiten. Nach Vorarbeiten von Franz Böttger und Emil Waschinski neu bearbeitet und erweitert, Neumünster 1990, s. 38).

73. "Schipfer" - en hyperkorrekt højtysk form for skipper - blev åbenbart tilføjet for at adskille denne Hans Hansen fra en anden HanB HanBen, der kun gav 12 sk. (fol. 16v) og som sandsynligvis levede $i$ ringere kår end skipperne.

74. En Christian Jürgensen [T]aan gav 1 mk. (fol. 20v). Måske er det samme person som den Christian Jürgensen Thun, der nævnes som "Kirchgeschworne[r]« i 1704 (Kirkeregnskabsbog Sonderborg (jf. n. 54), fol. $57 \mathrm{r}$ ).

75. $\mathrm{Pà} \mathrm{fol.} 7 \mathrm{r}$ findes en "Christian Jürgensen Tagl[öhner]", der betaler 4 sk. - eller betyder det blot, at han skulle betale dette beløb, og at det senere blev tydeligt, at han ikke havde giort det?

76. Knudsen: Sonderborg Skipperlang (jf. n. 5), s. 36, 118, 120; Lassen: Sønderborg Skipperlaug (jf. n. 59), s. 107; Bederegister mortensdag 1738 til mortensdag 1739 (jf. n. 48) (upagineret).

77. Kollektbog (jf. n. 71), fol. 11v. Han gav 1 mark.

78. Disse billeder hænger nu i opgangen til pulpituret. Det ene fremstiller Moses, det andet kunne måske være tænkt som Paulus, selv om ikonografien ikke stemmer helt.

79. Sveriges kyrkor. Gotland (jf. n. 2), bd. 2, s. 120-122, citat s. 122 .

80. Erland Lagerlöf og Gunnar Svahnström: Gotlands kyrkor. En vägledning, Stockholm 1991, s. 41; Johansson/Felderman/Franzén: Hellvitrakten (jf. n. 2), s. 154. Regnskabsbogen næevner kun udgifter i forbindelse med orglets indvielse (Landsarkivet i Visby: Hellvi kyrkoarkiv, L I a:3: Räkenskaper för kyrkan 1824-1858, s. 130). Et år tidligere var pulpituret blevet malet (s. 126).

81. Når O[tto] W[ilhelm] Lemke: Visby stifts herdaminne efter mestadels otryckta källor utarbetadt, Örebro 1868 , S. 159, skrev om kirken i Hellvi: "I vester är en läktare, uppförd och målad 1704 på bekostnad af 16 skeppare från Sonderburch, hvilkas alla namn stå upptecknade på en tafla", så skete det vist ikke efter selvsyn. Lemkes beskrivelse bekræfter placeringen, men næppe udseendet, fordi navnene dårligt kan adskilles fra billederne.

82. Sveriges kyrkor. Gotland (jf. n. 2), bd. 2 , s. 44 (retskrivningen i citatet følger originalen).

83. Steriges kyrkor. Gotland (jf. n. 2), bd. 4 , s. $135,137 \mathrm{f}$. (Norrlanda).

84. T[homas] O[tto] Achelis: "Laufküster und Sitzküster. Ein Beitrag zur Schul- und Kirchengeschichte des Amtes Hadersleben " i Schriften des Vereins fiir Schleswig-Holsteinische Kirchengeschichte, 2. r. 7 (1918-25), s. 420-433. 
85. Jf. Sveriges kyrkor. Gotland (jf. n. 2), bd. 1, s. $29 f$., 32 (Stenkyrka), 78f. (Martebo), 112f. (Lummelunda), 208, 211 (Väskinde), 448, 454 (Ekeby), 618 (Björke); bd. 9, h. 2, s. 80 f. (Grötlingbo); jf. også Bengt Stolt: "Kören och korbänken « i samme: Kyrkligt, kulturellt, gotländskt, Visby 2007 , s. 32-39, her s. $37 \mathrm{f}$.

86. Jf. Marie-Louise Jørgensen: »Sagregister" i Danmarks kirker. Sonderjylland. Tilfojelser og rettelser. Kunsthistorisk oversigt. Registre, København 1963 , s. 322-377.

87. Landsarkivet i Aabenraa: Sønderborg præstearkiv, nr. Cd 2: Stolestaderegistre ca. 1783 (upagineret) (citat); nr. Cd 3: Verzeichnis der Manns- und Frauens Stuhlständen [sic] in der Sonderburger MarienKirche 1783, s. 104-110; nr. Cd 4: Register über die Stuhlstände in der Kirche zu Sonderburg 1784, fol. 95v-102r; nr. Cd 4a: Register über Stuhlstände der Kirche zu Sonderburg. Verfertigt im Jahr 1784, fol. $95 \mathrm{v}-102 \mathrm{r}$.

88. Danmarks kirker, bd. 23: Sonderborg amt, ved Erik Moltke, Elna Møller og Vibeke Michelsen, København 1961 , s. 56.

89. For ordets skiftende køn i ældre højtysk, plattysk, dansk, svensk og gotlandsk, se Beyer: Gaver (jf. n. 1).

90. Landsarkivet i Aabenraa: Sønderborg præstearkiv, nr. Cd 1: Stolestaderegister 1602 - ca. 1780, fol. 110r: »auf hohen [sic] Chor auf der Süder Seiten«.

91. Danmarks kirker. Sonderborg ant (jf. n. 88), s. 56.

92. Landsarkivet i Visby: Lärbro [sic] kyrkoarkiv, A I: 1: Husförhörslängder 1737-1749 (upagineret). Dåbsfadet omtales heller ikke.

93. Rettet $\mathrm{i}$ håndskriftet fra men «.

94. Rettet $\mathrm{i}$ hăndskriftet fra met«.

95. Landsarkivet i Visby: Hellvi kyrkoarkiv, L I a:1: Räkenskaper för kyrkan 1651-1736, s. 156. Texten er blevet udgivet: [Anders R. Johansson (udg.):] Helloi LI:a-1. Kyrkoräkenskaper pro 1651-1735 (=Dokumentserien, bd. 3), [Lärbro 2000], anno 1703. Min lasning af hånd- skriftet adskiller sig på enkelte punkter fra Johanssons.

96. Hellvi kirkeregnskaber 1651-1736 (jf. n. 95), s. 157.

97. Indskriften på altertavlen er dateret til 1726 og nævner - som regnskabet for 1703 - "Andreas Fries" som giver. Sveriges kyrkor. Gotland (jf. n. 2), bd. 2, s. 120, formoder, at denne datering gælder malingen af altertavlen, men regnskabsbogen fortæller, at Fries stod for forgyldningen (Hellvi kirkeregnskaber 1651-1736 (jf. n. 95), anno 1726, upagineret). "Korbänken» kan efter sin form udmærket stamme fra ăret 1703. Godt nok indeholder den blot en hylde og ikke noget bord, men tidligere kunne ordet bord også betyde 'bräde, planka' (Ordbok öfuer svenska språket (jf. n. 47), bd. 5, 1925, sp. B 3892).

98. Munthe: Ur den gotländskn knlkindustriens historia (jf. n. 29), s. 99; Emilsson/Kavonius: Livet kring kalk och sten i Hellvi (jf. n. 26), s. 27f.

99. Danmarks kirker. Sonderborg amt (jf. n. 88), s. 46: "Johannes Willers Apothecker hat dieses Ao 1692 Von Neuen [sic] Staffieren lassen «. I modsætning til andre gaver af apotekeren bliver denne donation ikke nævnt i landsarkivet i Aabenraa: Sønderborg præstearkiv, nr. Ca 21: Donationsbog 1636-1731 (upagineret).

100. Navnet er ikke almindeligt. Muligvis omtaler folgende lejlighedstryk en slagtning: Wohlgemeyntes Schertz= und Ehren $=$ Gedicht / Auff das Hochzeitliche Frewden =Fest Des ... Herrn Levin Numens / berühmten Bïrgern und Kauffhändlern der Königl. Stadt Narva / gehalten daselbst am 7. Tage des Weinmonats dieses 1651. Jahtres mit der ... Jungfraucn Anna Gerkens / Des ... Herrn Albrecht Gerkens / Bürgers und Kauffmans in Hamburg Eheleiblichen Tochter, Tartu: Johann Vogel [1651].

101. Svahnström/Svahnström: Måleri (jf. n. 2), s. 147f.

102. Svahnström/Svahnström: Måleri (jf. n. 2), s. 149, 153.

103. Svahnström/Svahnström: Måleri 
(if. n. 2), s. 154; Sveriges kyrkor. Gotland (jf. n. 2), bd. 9, h. 2, s. 59 f. (Grötlingbo).

104. Landsarkivet i Visby: Rådhusrätten-Magistratens i Visby stad arkiv, F 1 A:14: Rådhusrätten och magistratens inneliggande handlingar 1700-1701.

105. Sveriges kyrkor. Gotland (jf. n. 2), bd. 2 , s. 42,48 .

106. Sveriges kyrkor. Gotland (jf. n. 2), bd. 1, s. 33 (Stenkyrka), 162 (Tingstäde); bd. 2, s. 180, 182 (Bäl); bd. 7, h. 3, s. 55 (Gerum); bd. 9, h. 2, s. 47, 55f., 82 (Grötlingbo); Svahnström/Svahnström: Måleri (jf. n. 2), s. 146 (Hejnum); [Torsten Gislestam:] Öja kyrka, [Öja] 1998, s. 13.

107. Landsarkivet i Aabenraa: Sonderborg præstearkiv, Bc 5: Sager til "Den gamle arkivfortegnelse «. Afd. 6, 1-3. Forskellige sager vedr. kirkevæesenet 1563-1831, mappe "Sager vedr. Orgelet" (indeholdende bl. a. "Register vnd Rekenschop der Nien Orgelen angewenthe vnkostinge ... van Anno [1] 1604. den 3 Iunij. beth an iegenwardigen dach vnd tidt. den 27 octobris Anno [1] 606:«); Kirkeregnskabsbog Sønderborg (jf. n. 54) (skifter til højtysk med året 1624, selv om samme skriver fortsætter); $\mathrm{nr}$. Cb 1: Kirkens skattelister 1607-09 (udelukkende på plattysk); Stolestaderegister(jf.n.90)(påbegyndtpå plattysk, men hurtigt skiftende til højtysk). Bøderegistrene (»Bröck Register«, "Brüch-Register «, jf. n. 48) er indtil 1640 fort på plattysk, derefter er der en lakune indtil 1695, hvorfra de fortsætter på højtysk. Adriansen: Sonderburg (jf. n. 37 , s. 12, daterer overgangen til $1623 / 24$, hvad der nok er lidt for firkantet. Om overgangen fra plattysk til højtysk $\mathrm{i}$ almindelighed, se Jürgen Beyer: »Der Beginn Dorpater Gelegenheitsdichtung in Volkssprachen. Mit einer Edition dreier niederdeutscher Gelegenheitsgedichte von Adrian Verginius aus dem Jahr 1638« i Christoph Schmelz og Jana Zimdars (red.): Innovationen im Schwedischen
Großreich. Eine Darstellung anhand von Fallstudien (=Schriftenreihe der David-Mevius-Gesellschaft, bd. 3), Hamborg: Dr. Kovãk 2009, s. $181-207$, her s. $182 \mathrm{f} ., 190 \mathrm{f}$.

108. Jf. Adriansen: Sonderburg (jf. n. 37), s. 16-24.

109. Landsarkivet i Aabenraa: Sønderborg og Nordborg amter indtil $1867 / 69$, nr. 120: Sager om Sønderborg amt og Sønderborg-Nordborg amt $\mathrm{i}$ almindelighed ... h) Sager om brugen af dansk og tysk sprog 1773-1811 (upagineret).

110. Lieder des Sonderburger Schiffer-Gelags, [Sonderborg 1924].

111. De højtyske arkivalier fra Sonderborg, fra hvilke der er blevet citeret i flere noter ovenfor, udviser i gvrigt også en stor usikkerhed i højtysk grammatik.

112. "GOTT ZV EHREN DER KIERCHEN ZIER.« og "LORENTZ MATZON RAADZSHER IN WIS$B \ddot{Y}$ « Transskriptionen følger originalen, jf. også Sveriges kyrkor. Gotland (jf. n. 2), bd. 2, s. 126.

113. Munthe: Ur den gotländska kalkindustriens historia (jf. n. 29), s. 107, 109; Emilsson/Kavonius: Livet kring kalk och sten $i$ Helloi (jf. n. 26), s. 25-27.

114. Sveriges kyrkor. Gotland (jf. n. 2), bd. 3, s. 360; jf. også P[er] A[rvid] Säve: Ur Handelns och näringarnas sagor från gutarnas ö. Kulturhistoriska bilder, Visby 1937, s. 23.

115. Dette mener også Åke G. Sjöberg: „Gotlands sjöfart stod på noll i det tidiga 1600-talets år« i [Robert Herlitz (red.)]: Skepparegillet $i$ Visby 1682-1982, Visby 1982, s. 7-17, her s. $14,16$.

116. Säve: Ur Handelns och näringarnas sagor (jf. n. 114), s. 23; Grandjean: De danske Gotlandsfarere (jf. n. 2), s. 68.

117. Johansson/Felderman/Franzén: Hellvitrakten (jf. n. 2), s. 154.

118. Carl Kihlén: "Vad den gamla sockenkyrkan berättade« i: Johannes Linnman [red.]: Gotland. Lärobok för skola och hem, Uppsala 1924, s. 241247, her s. 244.

119. Derimod findes der eksempler på 
sådanne gaver fra andre kirker, jf. Danmarks kirker, bd. 7: Bornholm, ved O. Norn, C.G. Schultz og Erik Skov, København: G.E.C. Gad 1954, p. 104; Finlands kyrkor, bd. 7: Åbolands prosteri, del 1, ved Sigrid Nikula, Helsingfors: Museiverket 1973, s. 194, 204.

120. Listerne over belabene fra fattigbøsserne synes at fortegne de aktive skipperes navne. Skipperlavet havde nemlig flere medlemmer, der ikke var skippere, f. eks. enker og håndværkere, jf. Döring: Das Schiffergelag (jf. n. 5), s. 446.

121. Protokolbog (jf. n. 36), f. eks. fol. 13r f., 18r, 25r f., 81v; Döring: Das Schiffergelag (jf. n. 5), s. 432, 437, 447-449.

122. Hellvi kirkeregnskaber 1651-1736 (jf. n. 95), s. 50 .

123. Lagerlöf/Svahnström: Gotlands kyrkor (jf. n. 80), s. 41.

124. Standsbevidsthed var vist også drivkraften, da kalkbrænderiejeren David Riper i 1681 ville bygge sin egen kirkestol i Hellvi Kirke
(Hellvi kirkeregnskaber 1651-1736 (jf. n. 95), p. 79). Angående Riper, se Munthe: Ur den gotländska kalkindustriens historia (jf. n. 29), s. 108; Emilsson/Kavonius: Livet kring kalk och sten $i$ Hellvi (jf. n. 26), s. 27.

125. Jf. Robert Murray: Finska församlingen $i$ Stockholm intill tiden för Finlands skiljande frän Sverige, Stockholm 1954; Jürgen Beyer og Johannes Jensen (red.): Sankt Petri Kopenhagen 1575-2000. 425 Jahre Geschichte deutsch-dänischer Begegnung in Biographien ..., København 2000.

126. Jf. ovenfor n. 114; Antjekathrin Graßmann: "Kirchliches Leben in den hansischen Niederlassungen des Auslandes" i samme (red.): Der Kaufmann und der liebe Gott. Zu Kommerz und Kirche in Mittelalter und Friiler Neuzeit (=Hansische Studien, bd. 18), Trier 2009, s. 113130; Danmarks kirker. Bornholm (jf. n. 119), s. 60; Sven Avnby: Sct. Michaelis Kirke. Tyske Kirke i Fredericia 1668-1993, Fredericia 1993, s. 12.

\section{Zusammenfassung}

Zwei Kirchen im Nordosten Gotlands, Hellvi und Rute, besitzen Inventar, dessen Inschriften davon berichten, dass Sonderburger Schiffer es gestiftet hätten. Der vorliegende Artikel beleuchtet die Hintergründe dieser Stiftungen. So wurde die Ausstattung der Kirche in Hellvi 1703 erneuert, wobei örtliche Honoratioren als Stifter tätig wurden. Die Sonderburger Schiffer schlossen sich dem offenbar an. Der Verfasser zeigt, dass bisherige, in der Forschung genannte Motive, für diese Stiftungen unwahrscheinlich sind und es sich eher um ein Zeichen der Dankbarkeit handelte, da die Schiffer über viele Jahre hinweg die Kirche regelmäßig nutzen konnten, ohne dort den Zehnten zu zahlen. 